\title{
ENTRE VACÂNCIAS E AS OCUPAÇÕES URBANAS: REPENSANDO O DIREITO À CIDADE A PARTIR DOS IMÓVEIS SUBUTILIZADOS NO CENTRO HISTÓRICO DE SÃO PAULO (SP)
}

\author{
BETWEEN VACANCIES AND URBAN OCCUPATIONS - RETHINKING THE RIGHT TO THE CITY: \\ UNDERUSED PROPERTIES IN SÃO PAULO'S HISTORIC CENTER
}

\author{
Fabiana Felix do Amaral e Silva ${ }^{1}$ \\ Lidiane Maciel $^{2}$ \\ Marina Cyrino Forti ${ }^{3}$
}

\begin{abstract}
${ }^{1}$ Possui graduação em Arquitetura e Urbanismo pela Universidade Presbiteriana Mackenzie (1999) e Mestrado (2006) e Doutorado (2011) em Ciências da Comunicação pela Universidade de São Paulo. Pós doutora no Programa de Mudança Social e Participação Política da EACH-USP.Pós doutora do PLUR-UNIVAP Atualmente é Professora e Pesquisadora do Programa em Planeamento Urbano e Regional - PLUR-UNIVAP, nos cursos de Mestrado e Doutorado. Pesquisadora e professora colaboradora do Centro de Estudos Latino-Americanos sobre Cultura e Comunicação - CELACC-ECA-USP. (cursos de Gestão em Projetos Culturais GESTCULT -CELACC-ECA-USP (2007-2011) e no curso de Mídia, Informação e Cultura MIDICULT-CELACC-ECA-USP (desde 2014). Tem experiência na discussão de movimentos sociais e territorialidades sócio-culturais-políticas, culturas urbanas e movimentos sociais latino-americanos, políticas públicas urbanas e espaços de participação social, metodologias e cartografias participativas. Na graduação também lecionou e desenvolveu pesquisas nos campos da Habitação Coletiva, do Planejamento Urbano e Regional, do Projeto Urbano e Paisagístico e sobre História e Teoria da Arquitetura e do Urbanismo. Na pós-graduação tem se dedicado à discussão da dimensão territorial como elemento essencial nos processos organizativos e reivindicatórios dos novos movimentos sociais e ações coletivas latino-americanos Universidade do Vale do Paraíba - UNIVAP - Brasil. ORCID: https://orcid.org/00000002-5754-9745 Lattes: http://lattes.cnpq.br/9584609707431515 E-mail: fabiana.amaral@gmail.com

2 Possui Graduação em Ciências Sociais pela Universidade Federal de São Carlos (2009), mestrado (2012) e doutorado (2016) em Sociologia pela Universidade Estadual de Campinas. Realizou estágio Sanduíche na Université de Paris - Ouest Nanterre (2014-2015) e é Pós-doutora pelo Departamento de Sociologia da Universidade Estadual de Campinas na área de técnicas e métodos de pesquisa social (2017). Docentepesquisadora na Faculdade de Educação e Arte, da Universidade do Vale do Paraíba (UNIVAP) e do Programa de Pós-graduação em Planejamento Regional e Urbano (PLUR ? IP\&D - UNIVAP). Pesquisadora do Projeto Temático FAPESP Observatório das migrações no Estado de São Paulo (NEPO/UNICAMP, coordenado pela Profa. Dra. Rosana Baeninger). Atualmente desenvolve um projeto de pesquisa regular no Instituto de Pesquisa e Desenvolvimento (IP\&D ? UNIVAP) com o título: deslocamentos (I) migratórios ocupações, desocupações e realocação de população na Região Metropolitana do Vale do Paraíba e Litoral Norte e Região Metropolitana de São Paulo. Como área de estudo inclui-se: Sociologia urbana, demografia/estudos populacionais e Planejamento Regional e Urbano. Universidade do Vale do Paraíba - UNIVAP. ORCID: https://orcid.org/0000-0002-5029-7645 Lattes: http://lattes.cnpq.br/8346883006355481 E-mail: lidiani.maciel@gmail.com

${ }^{3}$ Possui graduação em Arquitetura e Urbanismo pela Pontifícia Universidade Católica de Campinas (2016) e é pós-graduanda em Gestão de Projetos Culturais e Eventos no Centro de Estudos Latino-Americanos sobre Comunicação e Cultura (CELACC) na Universidade de São Paulo (USP).Mestranda no Programa em Planejamento Urbano e Regional da Universidade do Vale do Paraíba- PLUR-UNIVAP. Universidade do Vale do Paraíba - UNIVAP - Brasil. Lattes: http://lattes.cnpq.br/1730571802307167 E-mail: c.forti.marina@gmail.com
\end{abstract}




\section{RESUMO}

$\mathrm{O}$ artigo tem como objetivo discutir como o capital financeiro atua no espaço citadino produzindo vacância imobiliária em paralelo à luta dos movimentos sociais por moradia na cidade de São Paulo. 0 estudo foi realizado no centro histórico paulistano, especialmente, no Triângulo Histórico Sé. A metodologia se funda no levantamento de dados dos gabaritos, ou "pavimentos", dos prédios ocupados por moradias, comércios ou serviços, e dos imóveis de uso cultural, como é o caso dos prédios tombados naquela região. Realizou-se também um estudo etnográfico, entre os anos 2018 e 2019, em prédios ocupados por uma população com fortes traços de vulnerabilidade social e que se engaja em movimentos sociais de moradia. Como resultados e conclusões, verificou-se que o desenvolvimento urbanístico e, em alguma medida, também o ordenamento jurídico estatal, em função de regras e interesses da iniciativa privada, menosprezam os moradores da cidade, excluídos do direito à moradia. Porém, como práticas de resistência desenvolvidas nos últimos anos na cidade de São Paulo, os prédios vazios ou em vacância foram sendo ocupados por movimentos sociais que questionam a ordem vigente e a especulação imobiliária no centro da cidade e em seus entornos.

Palavras-chave: Cidade capitalista. Vacância imobiliária. Ocupação. Centro histórico de São Paulo. Movimento social.

\section{ABSTRACT}

The article aims to discuss how financial capital acts in space urbanites producing urban voids in parallel to the struggle of the social movements for housing in São Paulo. The study was conducted from the Historical Center of the same city, especially in the Historic Triangle Sé. The methodology is based on the survey of data of "floors" of buildings occupied by housing, commerce, or services, including cultural uses, as in the case of the listed buildings in this region. An ethnographic study was also carried out between 2018 and 2019 in buildings occupied by a population with strong traces of social vulnerability that engage in social housing movements. As results and conclusions, it was found that the urban development, and to some extent also the state legal system, due to rules and interests of the private initiative, belittles the residents of the city excluded from their right to it. However, as resistance practices in recent years in the city of São Paulo, the vacant or vacant buildings have been occupied by social movements that question the prevailing order and real estate speculation in the center and its surroundings.

Keywords: Capitalist city. Urban voids. Occupation. Historic Center of Sao Paulo. Social movement. 


\section{INTRODUÇÃO}

O espaço, conforme definido por Santos (1977), é um objeto social formado por um sistema de ações e objetos indissociáveis. Esses objetos condicionam as ações, assim como as ações virão a condicionar novos objetos. A formação do meio urbano influencia diretamente a vida de sua população e de sua relação com a cidade, fazendo com que o espaço deixe de ser apenas um conjunto de características geográficas e territoriais e passe também a ser um local de experiências sociais, onde se constitui a cultura no sentido mais amplo. Como defende Ferreira (2007), é preciso pensar o espaço como o lugar da reprodução do cotidiano:

Os diversos elementos que compõem a existência comum dos homens inscrevem-se em um espaço; deixam aí as suas marcas. Lugar onde se manifesta a vida, o espaço é condição, meio e produto da realização da sociedade humana em toda a sua multiplicidade [...] ao produzir sua existência, a sociedade reproduz, continuamente, o espaço. (FERREIRA, 2007, p. 43).

O espaço urbano, desta maneira, é produzido socialmente por meio da produção, circulação e consumo feitos pelas lutas sociais que acontecem em torno das condições de vida cotidiana (HARVEY, 2014). Os espaços comunitários se tornam fundamentais para formação de laços e de desenvolvimento político e social. Desse modo, o direito coletivo à cidade implica no uso social do espaço e na apropriação pelo corpo, tornando o espaço público "um lugar para debates e discussões abertas sobre o que esse poder está fazendo e qual seria a melhor maneira de se opor a ele" (HARVEY, 2014 , p. 281). No entanto, percebe-se, em uma avaliação rápida das cidades brasileiras, que a desigualdade emergente impede uma parcela da população de exercer o direito à cidade. Em paralelo a esse processo, verificam-se as mesmas cidades sendo apropriadas tão somente pela lógica mercadológica.

Considerando essas premissas, o artigo tem como objetivo repensar a dimensão do direito à cidade a partir da análise das dinâmicas presentes nos fenômenos da vacância imobiliária e das ocupações urbanas com o intuito de pontuar possíveis caminhos para pensar novas formas de produzir a cidade.

O fenômeno da vacância imobiliária, isto é, os vazios construídos sem uso funcional, em áreas centrais como as da cidade de São Paulo é medido por meio da relação entre a contagem de propriedades vagas e a quantidade de propriedades construídas, calculada por unidade ou por metro quadrado e distinguida por tipo de uso: residencial, comercial ou industrial. O cálculo serve como 
parâmetro para o poder público verificar o índice de inadimplência em relação à taxa de impostos ou a uma subutilização da infraestrutura implantada. O mesmo cálculo serve para o setor privado como direcionador de investimentos (BONFIM, 2004; CARTY; COSTA, 2017).

A vacância está relacionada com mudanças no direcionamento dos eixos econômico (produção e consumo), tecnológico, político e cultural vividos pelas cidades. Essas alterações resultam em uma nova lógica de ocupação espacial da cidade contemporânea. A construção de novos espaços pela iniciativa privada, em locais de seu interesse, leva a população a se deslocar para outras regiões da cidade, o que torna quase certa a vacância nas áreas centrais.

Este fenômeno evidencia uma contradição urbana, pois as áreas centrais possuem uma elevada infraestrutura, principalmente no que se diz respeito ao transporte público e à concentração de empregos. Nos últimos anos, diversas cidades brasileiras têm implementado políticas públicas chamadas de requalificação ou revitalização de áreas centrais, com a finalidade de atrair investidores dos setores de bares/serviços e culturais, ligados ao turismo patrimonial. Conforme citado pelos pesquisadores Vanessa Gapriotti Nadalin e Renato Balbim (2011):

Para o Brasil como um todo, por exemplo, existiam em 20006.029 .756 domicílios vagos, enquanto o déficit habitacional foi estimado em 5.890 .139 unidades. Ou seja, feita uma comparação simples, haveria mais domicílios vagos no Brasil nos anos 2000 que os necessários para cobrir o déficit habitacional estimado nessa mesma época. (NADALIN; BALBIM, 2011, p. 2).

Tabela 1: evolução da distribuição dos domicílios particulares não ocupados no

$$
\text { Brasil - 1991, 2000, } 2010 \text { (\%) }
$$

\begin{tabular}{cccc}
\hline & $\mathbf{1 9 9 1}$ & $\mathbf{2 0 0 0}$ & $\mathbf{2 0 1 0}$ \\
\hline Brasil & $15.60 \%$ & $17.00 \%$ & $14.85 \%$ \\
Salvador - BA & $18.20 \%$ & $17.50 \%$ & $17.18 \%$ \\
Belém - PA & $15.90 \%$ & $15.40 \%$ & $15.14 \%$ \\
Rio de Janeiro - RJ & $14.10 \%$ & $14.70 \%$ & $13.54 \%$ \\
Recife - PE & $12.10 \%$ & $15.40 \%$ & $13.28 \%$ \\
Distrito Federal & $10.30 \%$ & $13.10 \%$ & $12.30 \%$ \\
Fortaleza - CE & $14.50 \%$ & $16.30 \%$ & $12.04 \%$ \\
\hline
\end{tabular}




$\begin{array}{cccc}\text { São Paulo - SP } & 10.50 \% & 15.10 \% & 11.39 \% \\ \text { Porto Alegre - RS } & 9,9 \% & 10.90 \% & 11.34 \% \\ \text { Curitiba - PR } & 11,00 \% & 13.00 \% & 11.06 \%\end{array}$

Fonte: Censo demográfico IBGE 1991, 2000, 2010. apud NADALIN, BALBIM, 2011, p.2).

Conforme a Tabela 1 mostra, o problema da vacância é algo considerável nas principais capitais brasileiras. A evolução da distribuição dos domicílios particulares não ocupados no Brasil evidencia que, passados quase trinta anos, $(1991-2010)$ as taxas seguem acima de $10 \%$ nas cidades listadas. Neste embate, surgem nos territórios outras estratégias de ocupação e uso do espaço, e são nesses "espaços vazios" que se encontram histórias de ocupações, moradias improvisadas realizadas por famílias de trabalhadores, especialmente, do centro. Este fato pode ser observado nas cidades de Belo Horizonte, Rio de Janeiro, Recife e São Paulo (TRINDADE, 2018; CANETTIERI, 2017; LELIS, 2016).

As ocupações são majoritariamente organizadas por movimentos sociais pró-moradia, mas também por grupos e agentes autônomos que se apropriam de "espaço vazio" e o alugam para pessoas em situação de rua ou vulnerabilidade social. As ocupações, quando organizadas por movimentos sociais, têm como bandeira o direito à moradia e se apoiam no artigo 182 da Constituição Federal de 1988, que versa sobre a função social da propriedade urbana ${ }^{4}$.

Considerando estas questões, o presente artigo apresenta o estudo empírico do o Triângulo Histórico Sé ${ }^{5}$, formado pela Rua Direita, a Rua São Bento e a Rua do Rosário - hoje Rua XV de Novembro -, e adotado como estudo de caso devido à incidência de imóveis na condição de vacância e de ocupações irregulares nesta região.

A metodologia do artigo propõe correlacionar os resultados e análises de dois trabalhos de campo realizados pelas autoras. O primeiro, realizado em 2018, visou identificar espaços de vacância no centro de São Paulo. Verificou-se, inicialmente, a que usos eram destinados os imóveis no momento de sua construção e se eles ainda são ocupados pelos mesmos moradores atualmente. Por fim, os

\footnotetext{
${ }^{4}$ Art. 182. (...) § 40 - É facultado ao Poder Público municipal, mediante lei específica para área incluída no plano diretor, exigir, nos termos da lei federal, do proprietário do solo urbano não edificado, subutilizado ou não utilizado, que promova seu adequado aproveitamento, sob pena, sucessivamente, de:

I - Parcelamento ou edificação compulsórios;

II - Imposto sobre a propriedade predial e territorial urbana progressivo no tempo;

III - desapropriação com pagamento mediante títulos da dívida pública de emissão previamente aprovada pelo Senado Federal, com prazo de resgate de até dez anos, em parcelas anuais, iguais e sucessivas, assegurados o valor real da indenização e os juros legais. (BRASIL, 1988).

${ }^{5}$ A nomenclatura triângulo da Sé ou centro histórico é uma categoria amplamente utilizada pela própria Prefeitura de São Paulo (CIDADE DE SÃO PAULO, 2019).
} 
resultados dessa etapa foram relacionados com o surgimento e a permanência de espaços edificados vazios no local. No caso da cidade de São Paulo, encontram-se dados sobre o número e a porcentagem de domicílios não ocupados, mas nenhum dado passível de comparações com outras variáveis, como uso e ocupação. A segunda etapa foi caracterizada pelo estudo do gabarito local ${ }^{6}$, com a finalidade de analisar se ele também influencia ou se contradiz à vacância local. Para a pesquisa, optou-se pelo levantamento lote a lote da área delimitada pelo triângulo formado pelas ruas São Bento, XV de Novembro e Direita e seu entorno imediato, no mês de novembro de 2018. Nesta área, concentra-se um intenso comércio.

No segundo momento da pesquisa, relacionaram-se os dados obtidos pelo levantamento com um estudo etnográfico, realizado entre 2018 e 2019, em cinco ocupações do centro da cidade de São Paulo, localizadas nas cercanias do Triângulo Histórico da Sé.

Com o objetivo de evidenciar os aspectos das sociabilidades presentes em quadros de vulnerabilidades e que expressam outras estratégias de ocupação, uso e controle popular dos territórios (ZIBECHI, 2008), optou-se pela apresentação das análises etnográficas de uma ocupação urbana no Triângulo da Sé. Assim, este artigo está organizado em três partes. A primeira traça algumas questões vinculadas à problemática histórica da cidade de São Paulo e à formação do Triângulo Histórico da Sé. A segunda parte discute os espaços de vacância por meio da composição de uma cartografia. E a terceira e última parte se apoia na discussão das contradições emergentes (HARVEY, 2005) entre vacância imobiliária, déficit habitacional, ocupações urbanas e direito à cidade na realidade da cidade de São Paulo. Essas dimensões impelem muitos trabalhadores a se engajarem no movimento por moradia ou a alugarem unidades em prédios abandonados e apropriados por agentes imobiliários não formais.

\section{CARACTERÍSTICAS URBANAS E A VACÂNCIA NO TRIÂNGULO HISTÓRICO DA SÉ}

O Distrito Sé, ou "Centro Velho", está localizado na zona central da cidade de São Paulo, possui uma área de 219 hectares e é administrado pela Subprefeitura da Sé. Segundo a Coordenadoria de Produção e Análise de Informação da Secretaria Municipal de Urbanismo e Licenciamento, o distrito possuía 25.764 habitantes em 2017, com uma população predominantemente jovem, entre 25 e 29 anos. De acordo com o Censo Demográfico de 2010, essa população está distribuída em 9.098

\footnotetext{
${ }^{6}$ Limite regulamentar de altura imposto pela legislação às edificações dentro de uma determinada área (HOUAISS, 2001).
} 
domicílios (93\% apartamentos, sendo 52\% deles imóveis próprios) habitados por dois ou três moradores, com um rendimento domiciliar mensal entre dois e cinco salários-mínimos.

O local é cercado pelos rios Anhangabaú e Tamanduateí e ladeado, ao norte, pela Avenida Mauá e distritos de Bom Retiro e Luz, o leste, pela Avenida do Estado e distrito do Brás e Canindé, ao sul, pela Avenida Radial Leste e Liberdade e, a oeste, pela Avenida Prestes Maia e distritos República e Santa Ifigênia. É abastecido pelo sistema de transporte viário, com vias de fluxo intenso, como a Avenida Rangel Pestana, a Avenida da Liberdade e a Rua 25 de Março, e pelo sistema de transporte coletivo, com duas linhas e seis estações de metrô, faixas exclusivas para ônibus, o Expresso Tiradentes, o Terminal Parque Dom Pedro II e a Estação da Luz da Companhia Paulista de Trens Metropolitanos (CPTM). Essa estrutura, associada à oferta de 91.459 empregos formais, segundo a relação de 2016 do Ministério do Trabalho e Emprego (MTE), faz com que a área central receba cerca de dois milhões de pessoas todos os dias em horário comercial, resultando em um intenso tráfego de passagem de pedestres e veículos.

Nas últimas décadas, as grandes e médias cidades passaram por perda de habitantes nas áreas centrais e por crescimento nos bairros afastados e periféricos. Um dos principais motivos para tal acontecimento é a segregação espacial acarretada pela ação do poder público em relação a políticas habitacionais, a saber, a construção de grandes conjuntos habitacionais em áreas carentes de infraestrutura e quilômetros distantes dos centros (VILLAÇA, 2011).

Como explica Villaça (1998), a partir da década de 1960, com o desenvolvimento da indústria automobilística, a cidade de São Paulo se expandiu a partir do vetor sudoeste (sentido Marginal Pinheiros). As elites, então, se afastaram do centro, e com elas foram os investimentos estatais antes ali concentrados. Com este processo, o centro histórico "degradou-se" - em detrimento do surgimento de novos bairros - e foi tomado pelos setores de comércio informais e serviços empresariais: "Com o abandono das camadas de alta renda, os valores imobiliários diminuíram, possibilitando o acesso das camadas populares, para as quais passaram também a se orientar parte dos serviços e o comércio do Centro" (KARA-JOSÉ, 2007, p. 66).

Segundo Barbosa (2001), o domínio sociopolítico e o planejamento urbano vão em direção ao favorecimento da expansão das dimensões espaciais da cidade, o que leva à dispersão urbana, que tem como origem uma sucessão de ciclos econômicos e a espacialização de fenômenos. Isso reflete os efeitos existentes desde os tempos da colonização e do povoamento territorial, e propicia o desenvolvimento de novas centralidades de acordo com os interesses imobiliários e capitalistas. 
A cidade passou por um processo de expansão territorial apoiado na instalação de infraestrutura urbana em novas áreas, com base na presença do automóvel, do investimento de capital público e privado, e com deslocamento dos próprios órgãos públicos. (BARBOSA, 2001 apud BONFIM, 2004, p. 45).

Segundo Nestor Goulart Reis Filho (2017), a urbanização dispersa pode ser vista como um processo contínuo e crescente enquanto multiplicam-se complexos comerciais, culturais e conjuntos urbanísticos. Esse fenômeno acarreta efeitos sobre o meio físico e social e sobre o patrimônio construído, podendo alterar centralidades, aumentar as demandas por mobilidade e atingir tanto a população de alta renda quanto a de baixa renda: "o processo de dispersão urbana caracteriza-se pelo esgarçamento do tecido urbano, com a urbanização estendendo-se por um vasto território, com núcleos urbanos separados no espaço por vazios intersticiais" (REIS FILHO, 2017, p. 602).

A desocupação de edifícios em áreas centrais também está relacionada com a esfera tecnológica, já que esses imóveis passam a ser obsoletos por não possuírem a infraestrutura necessária para receberem novas atividades, tornando-os incompatíveis com as atividades atuais, tanto de comércio como de moradia. Uma comparação entre os custos de manutenção das construções e os lucros estimados por meio de sua ocupação posterior acaba induzindo ao abandono dos imóveis, já que passa ser mais rentável investir em terras urbanas de menor valor em outras regiões da cidade, onde a legislação urbana é mais favorável à verticalização (BONFIM, 2004).

Com o "esvaziamento populacional" dos centros e suas unidades de habitação fechadas, os investimentos públicos em infraestrutura passam a se concentrar em outras áreas, assim como ocorre com os financiamentos destinados à produção e comercialização imobiliária. Tais ações levam a queda do valor de comercialização das propriedades, o que faz com que proprietários prefiram esperar uma futura revalorização a vender ou locar os imóveis (VILLAÇA, 1998). Este fenômeno retrata parte da lógica da produção capitalista do espaço, em que os capitais financeiros atrelados à dominação política têm assumido a gestão dos territórios.

Tratando-se da área de estudo, com o crescimento do mercado industrial a partir de 1929 (momento da quebra da Bolsa de Valores de Nova York), as indústrias e serviços precisaram se instalar em locais que suprissem as condições espaciais e ambientais para adotar novas tecnologias, tais como sistema de refrigeração, suporte para um considerável aumento do consumo de energia elétrica, acessibilidade através de elevadores, entre outras que não poderiam ser encontradas em edifícios antigos e que demandavam investimentos de custo elevado para adaptações. Além disso, a ausência de terrenos vazios para a construção de novos edifícios empresariais resultou na procura de locais fora do perímetro central. Esses locais se tornaram as novas centralidades de São Paulo - Paulista, Faria 
Lima e Berrini -, que começaram a surgir no final da década de 1960 e a se consolidar na década de 70, época de forte crescimento econômico. Eles passaram, então, a disputar investimentos imobiliários e de infraestrutura com a região central, e, assim, as indústrias e serviços encontraram nesses novos centros as condições necessárias para a adoção das novas tecnologias empresariais e administrativas (SANDRONI, 2004).

Ao mesmo tempo, com a valorização dos terrenos e com a criação de leis ambientais, como a Lei do Parcelamento do Solo Urbano (Lei n. 6.766/1979), que controla não apenas os aspectos urbanísticos, mas também os efeitos causados ao meio ambiente e à saúde pública (MOTTA; PÊGO, 2013), empresas antes instaladas na cidade transferiram suas sedes para o interior do estado de São Paulo e mantiveram, na capital, suas atividades administrativas em locais estratégicos e de fácil acesso ao transporte rodoviário e aéreo, ou seja, nas marginais Pinheiros e Tietê. Apesar de totalmente acessível por meio de transporte público, a região central tornou-se "distante" para meios de transporte individuais, devido a sua localização e à falta de garagens (SANDRONI, 2004).

Essa nova dinâmica resultou em decréscimo de investimentos públicos e privados e em uma queda drástica no número de habitantes, visto que mais de 10.000 pessoas se deslocaram para outros locais da cidade (SANDRONI, 2004). Porém, a Subprefeitura Sé continua, ainda hoje, com a maior concentração de empregos formais e informais da metrópole, em torno de $20 \%$ dos empregos do município (CIDADE DE SÃO PAULO, 2020).

O centro de São Paulo possui uma densidade demográfica ainda diferente do restante, tendo na maior parte do território, segundo o Setor Censitário de 2010, valor de até 92 habitantes por hectare, ocupado predominantemente por edificações consideradas patrimônios culturais e, por isso, tombadas. Como pode ser visualizado nos Gráficos 1 e 2, o número de habitantes do distrito Sé teve um comportamento contrário ao número de habitantes da cidade de São Paulo, pois registrou uma queda drástica entre os anos 1980 e 2000, com a locomoção de mais de 10.000 pessoas para outros locais da cidade. 
Gráfico 1 - Número de habitantes da cidade de São Paulo 1950-2015

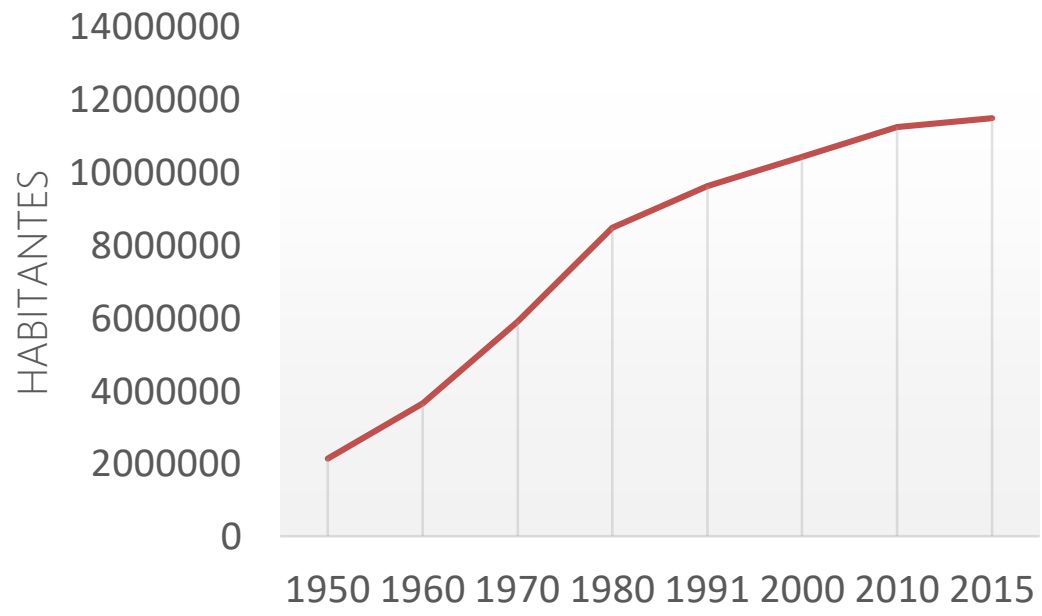

Fonte: Secretaria Municipal de Desenvolvimento urbano - IBGE

Gráfico 2 - Número de habitantes do Distrito Sé

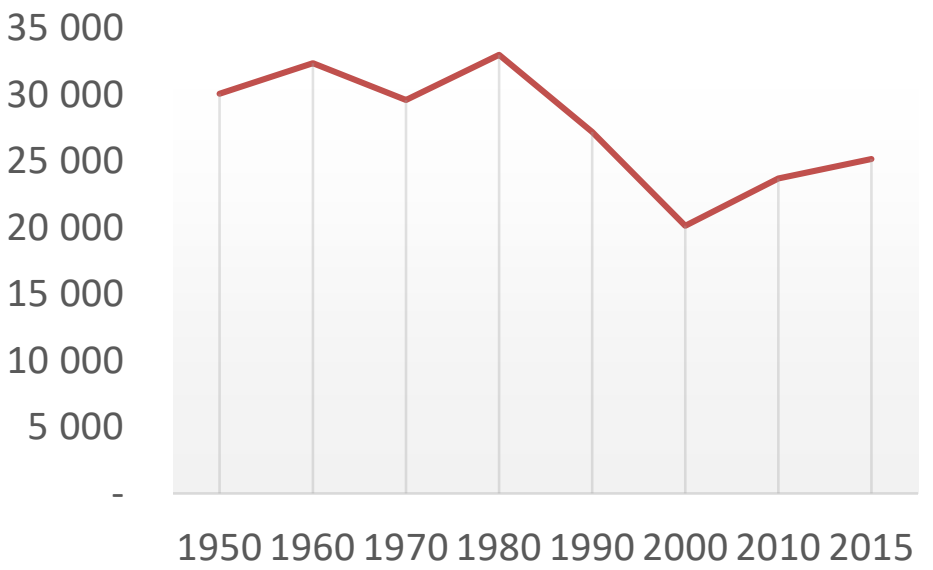

Fonte: Secretaria Municipal de Desenvolvimento urbano - IBGE 2015 
Como se pode avaliar no Gráfico 2, produzido com base em dados da Prefeitura Municipal de São Paulo, de 2000 até o momento atual, o número de habitantes voltou a crescer lentamente. Enquanto a população paulistana cresceu $7,9 \%$ na última década, a população do distrito Sé cresceu 17,6\%. Houve também uma mudança significativa no número de domicílios: em relação ao censo de 2000 , o de 2010 registrou um crescimento de $19 \%$.

Por ser a região de São Paulo mais abastecida por transportes públicos (metrô e ônibus), a procura pelo centro é feita por pessoas que querem economizar tempo de deslocamento sem depender do transporte individual. Outro fator de extrema importância para o aumento do número de habitantes foi a mudança dos edifícios da administração pública para o local, o que atraiu funcionários com renda fixa que optaram por morar próximos ao trabalho.

A procura pela moradia no centro resultou em grande queda no número de vacâncias. Em uma década, o número de imóveis vazios na Sé despencou de 35,2\% (2000) para 11,6\% (2010), ou seja, passou de 10.062 para 4.978 imóveis vazios. Trata-se de uma queda de quase $70 \%$, maior do que a queda da cidade de São Paulo, que passou de 14\% para 7,5\%. Porém, o número ainda é alto levando em consideração que o índice adequado deve variar entre 5 e 7\%. Logo, apesar de ter recebido novos moradores, a perspectiva ainda está longe de ser revertida.

\section{ANÁLISE DO TRIÂNGULO HISTÓRICO SÉ E SEUS USOS}

O centro histórico é um bairro com um número significativo de apartamentos. Segundo o censo do IBGE, em 2010, o distrito Sé possuía 8.445 apartamentos, constituindo 92,8\% dos imóveis da região. $O$ impacto dessa variável na vacância é alto, pois edifícios de apartamentos permitem reformas muito mais restritas que as reformas possíveis em uma casa, o que dificulta a mudança em seu uso, por exemplo. Outro fator relacionado ao número de apartamentos é que muitos dos imóveis verticalizados possuem um único proprietário, sem fracionamento da propriedade, o que dificulta a realização de reformas e a aplicação de capital para sua operacionalidade devido ao alto valor necessário para um investimento (BONFIM, 2004).

Outra característica do Triângulo Histórico Sé é, como em todo centro, o uso bastante heterogêneo do espaço. Nessa área predominantemente verticalizada, encontra-se um uso misto feito por comércios no térreo e escritórios ou moradias nos demais pavimentos. Porém, grande parte dos imóveis está desocupada há mais de um ano. 
A área estudada é composta por edifícios tombados em instância municipal e em instância estadual. A Igreja de Santo Antônio e a Residência de Elias Pacheco Chaves, por exemplo, foram tombadas pelo Conselho Municipal de Preservação do Patrimônio Histórico, Cultural e Ambiental da Cidade de São Paulo (CONPRESP). Já o Conselho de Defesa do Patrimônio Histórico, Arqueológico, Artístico e Turístico (CONDEPHAAT), órgão subordinado à Secretaria da Cultura do Estado de São Paulo, tombou imóveis como o Edifício do Centro Cultural Banco do Brasil (CCBB) e o Edifício Banco de São Paulo. Esses edifícios são divididos por nível de proteção, sendo P-1 a preservação integral, P-2 a preservação integral de todos os elementos externos e elementos internos discriminados nas fichas cadastrais do processo de tombamento e P-3 a determinação de preservação apenas de elementos da fachada.

A partir dessas considerações e das análise de pesquisa, foi possível verificar que nas onze quadras que formam o Triângulo Histórico Sé e seu envoltório predomina o uso misto dos espaços. Esse resultado, em números, significa que 105 (58\%) dos lotes possuem áreas destinadas à residência e, entre esses edifícios, apenas 33 (31\%) deles possuem gabarito de um a três andares, na maioria das vezes com os pavimentos superiores destinados à residência. Apesar da grande oferta residencial, a maior parte das construções destinadas a uso misto está ocupada apenas no espaço destinado ao uso comercial, ou seja, no pavimento térreo. Encontram-se, inclusive, quadras sem edifícios exclusivamente residenciais. Nos outros andares, encontra-se a vacância ou adaptações para receber salas comerciais, mas resta a verificação do título de propriedade do prédio.

Por mais que se tenha uma política insistente nas propostas de requalificação, cuja finalidade é transformar edifícios tombados em espaços culturais, o que se vê na área estudada é que apenas três dos 54 edifícios seguiram essa lógica. Os outros 51 imóveis possuem um nível de proteção patrimonial de P-2 ou P-3, o que faz deles passíveis de serem ocupados, mesmo se tratando de quadras com um terço dos lotes tombados. Logo, a argumentação sobre a dificuldade de se obter políticas habitacionais no centro histórico devido à dificuldade de adaptação do patrimônio para usos atuais deixa de fazer sentido.

Vale destacar a quadra número 9 (ver quadras selecionadas na Figura 1) por ser muito representativa na ocupação do espaço urbano pelo capital financeiro. Quase metade dos seus lotes é ocupada pelo Banco do Brasil, e o restante, por inúmeros escritórios do mercado financeiro.

Levantados os dados, verificou-se que há uma grande incidência de áreas destinadas à ocupação mista, porém a vacância permanece alta. Nesses edifícios mistos, o piso térreo é ocupado por comércios e serviços, sobretudo por grandes empresas, que ditam as regras do espaço urbano. Deste modo, as relações capitalistas de produção estabelecidas no meio urbano, com base na 
organização das classes econômicas dominantes, mantêm o desenvolvimento urbano sob seu controle, constituindo mecanismos capazes de se apropriar de práticas sociais e culturais. A exploração dessa atmosfera permite que os investimentos nos setores imobiliário e turístico sejam valorizados, tornando a cidade, seus habitantes e seu patrimônio histórico uma mercadoria única.

Desse modo, é possível dizer que, no Triângulo Histórico da Sé, há uma problemática emergente em torno da apropriação do espaço que retrata a dinâmica da gestão neoliberal dos territórios, a qual têm transferido para setores financeiros o poder de decisão e condução da produção do espaço. Neste sentido, avalia-se neste estudo que a subutilização dos imóveis desafia a gestão municipal, incapaz de controlar tal dinâmica e de garantir uma política habitacional extensiva e inclusiva.

No Projeto de Lei n. 619/167 (Plano de Habitação Municipal), no capítulo IV, intitulado "Dos instrumentos indutores da função social da propriedade urbana", artigo 110, encontra-se descrita a aplicação do "Parcelamento, Edificação e Utilização Compulsórios - PEUC, (...), quando esse instrumento puder fomentar a produção privada de Habitação de Interesse Social em imóveis não edificados, subutilizados ou não utilizados, em articulação com os programas habitacionais" (p. 33).

\footnotetext{
${ }^{7}$ Vale salientar, que até o momento de elaboração deste artigo este projeto de lei ainda não havia sido votado pela Câmara dos vereadores.
} 
Figura 1-Quadras selecionadas para a pesquisa de campo

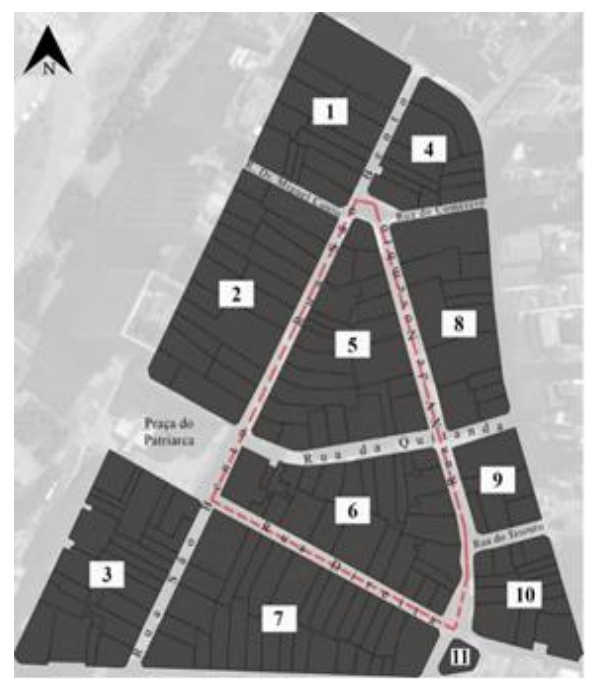

Figura 3: Uso e ocupação

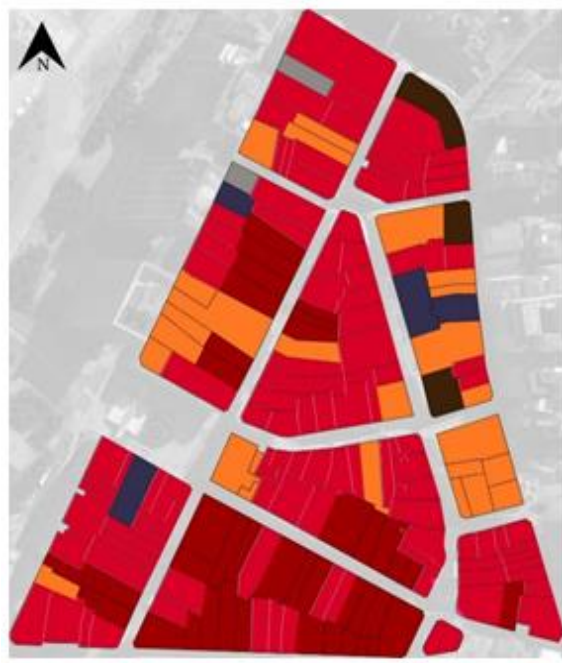

\section{Comercial}

Serviço

Misto (comercial e residencial)

Institucional

Cultural

Estacionamento
Figura 2 - Edifícios tombados

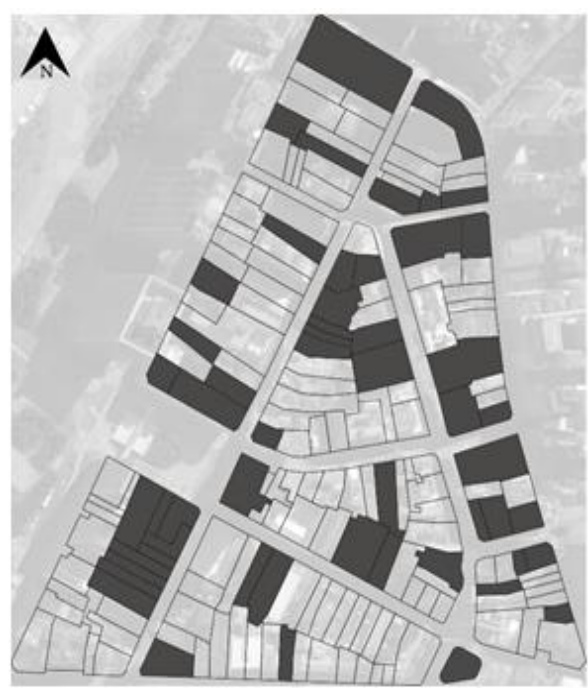

Figura 4 - Gabarito

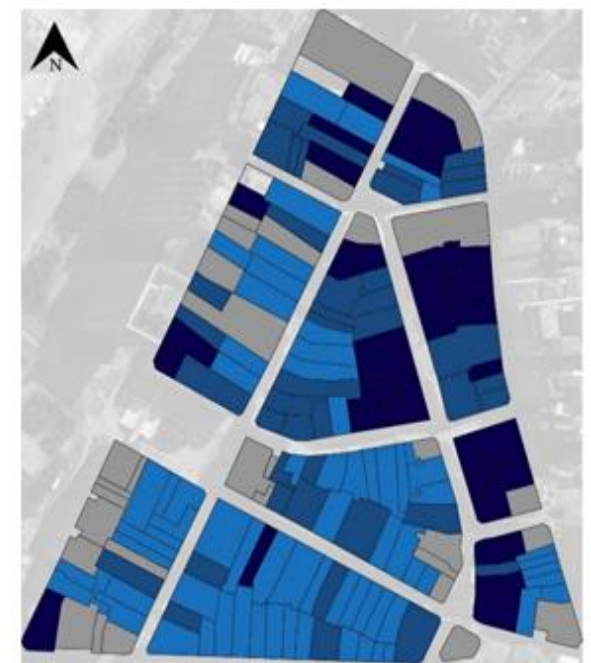

1 a 3 pavimentos

4 a 6 pavimentos

7 a 10 pavimentos

Mais de 11 pavimentos

Fonte: autoras. 


\section{VACÂNCIA IMOBILIÁRIA, DÉFICIT HABITACIONAL, OCUPAÇÕES URBANAS E DIREITO À CIDADE ${ }^{8}$}

Os dados apresentados no tópico anterior levam à reflexão sobre a questão de que o uso dos espaços no centro de São Paulo e a formação dos vazios e áreas subutilizadas estão relacionados à organização capitalista do espaço segregado, que, desta forma, determina as áreas de especulação imobiliária. Parte do mesmo processo é o elevado número de pessoas sem moradia. No caderno para discussão pública, referente ao Plano Municipal de Habitação de 2016 (PREFEITURA MUNICIPAL DE SÃO PAULO, 2016), os dados tabulados pelo Centro de Estudos da Metrópole (CEM) permitiram constatar que, em 2010, a cidade de São Paulo tinha um déficit habitacional de 358.097 mil moradias, no entanto, 1.385 imóveis estavam ociosos (abandonados ou subutilizados e terrenos sem edificações).

Este quadro apresenta os dilemas e as contradições do capital expressos na produção e ocupação do espaço. Entende-se, portanto, que a cidade e seus territórios servem à expansão e reprodução do capital. Conforme Harvey (2014):

A cidade tradicional foi morta pelo desenvolvimento capitalista descontrolado, vitimada por sua interminável necessidade de dispor de acumulação desenfreada de capital capaz de financiar a expansão interminável e desordenada do crescimento urbano, sejam quais forem suas consequências sociais, ambientais ou políticas. (HARVEY, 2014, p. 20).

Desta forma, a cidade é um palco de disputas cujos princípios do direito à cidade aparecem nas discussões das lutas sociais por meio direito de apropriação do centro urbano pelas classes populares. Lefebvre (1968) já apresentava o espaço urbano como uma arena produzida pela luta política e ideológica. A produção social do espaço se realiza na gestão da própria vida na cidade, constituída por inúmeras contribuições derivadas do trabalho daqueles que a habitam e que, consequentemente, seriam os detentores do direito à sua apropriação.

\footnotetext{
8 "Os documentos de referência para a compreensão do direito à cidade como um direito humano emergente na nova agenda urbana são os seguintes: Carta Mundial do Direito à Cidade (2005); Carta Europeia dos Direitos Humanos nas Cidades (Saint-Denis, 2000); Direitos Humanos nas Cidades - Agenda Global (Cidades e Governos Locais Unidos - CGLU, do inglês United Cities and Local Governments - UCLG, 2009); Carta da Cidade do Direito à Cidade (México, 2009); Carta do Rio de Janeiro sobre o Direito à Cidade (Fórum Urbano Mundial, 2010); Por um Mundo de Cidades Inclusivas (Comitê de CGLU sobre a Inclusão Social, Democracia Participativa e Direitos Humanos, de 2013); Inclusão Social e Democracia Participativa e os Princípios Gwangju para uma Cidade dos Direitos Humanos (2015). Nos sistemas legais nacionais destaca-se a legislação brasileira Estatuto da Cidade (2001) e a Constituição do Equador, que contém uma definição legal do direito à cidade" (SAULE JÚNIOR, 2016, p. 76).
} 
Todavia, mesmo que a política urbana brasileira seja considerada uma das mais avançadas do mundo em termos de legislação, são vários os desafios da vida nas cidades. A lei do Estatuto da Cidade (Lei Federal n. 10.257/2001) tem como base jurídica, por exemplo, o princípio da função social da cidade e da propriedade. Dessa forma, o setor público pode regular o uso da propriedade. No entanto, este princípio jurídico é corriqueiramente abandonado pelas políticas públicas urbanas, restando aos movimentos socioterritoriais urbanos o seu resgate. Eles o utilizam para legitimar suas ações e reivindicações, principalmente aquelas referentes à ocupação de imóveis que estejam ociosos e que não cumpram a função social.

Em São Paulo, em relação à legislação municipal sobre habitação, vale citar que, em 2016, ainda na gestão do prefeito Fernando Haddad (2013-2016), foi elaborado o Plano Municipal de Habitação (Projeto de Lei n. 619/2016), que, a partir de três linhas programáticas (Serviço de Moradia Social, Provisão de Moradia e Intervenção Integrada em Assentamento Precários), pretendia nortear as ações e medidas a serem adotadas no âmbito das políticas habitacionais pelos próximos dezesseis anos.

Para a luta dos movimentos de moradia, a proposta estava em consonância ao cumprimento da função social da propriedade ao criar, por exemplo, dentro do eixo de serviço de moradia social, a discussão sobre ações transversais vinculadas à atuação integrada na área central, à viabilização dos imóveis para o serviço de moradia social e às estratégias direcionadas aos edifícios particulares notificados para parcelamento de edificação e utilização compulsórios (PEUC). Esse instrumento urbanístico busca garantir a função social da propriedade ao combater a ociosidade dos edifícios, que são frequentemente objetos de ocupações, de pedidos de reintegração de posse e de ações judiciais.

O Plano Municipal de Habitação de São Paulo - Caderno para discussão pública, de junho de 2016, indica que a Prefeitura de São Paulo já havia notificado cerca de mil imóveis ociosos na área central por meio do:

Parcelamento Edificação e Utilização Compulsórios (PEUC), no centro da cidade e nas áreas de Operações Urbanas Consorciadas (OUC), sob pena de aumento anual do IPTU e, após 5 anos, de desapropriação com títulos da dívida pública para fins de moradia. Esse é o instrumento atualmente à disposição do Poder Público para combater a ociosidade desses edifícios, frequentemente objeto de ocupações e de pedidos de reintegração de posse, ações judiciais nas quais a prefeitura não tem parte e tem poder de intervenção limitado. (PREFEITURA MUNICIPAL DE SÃO PAULO, 2016, p. 14).

No eixo referente ao serviço de moradia social, mais especificamente na discussão sobre a viabilização dos imóveis para o serviço de moradia social estratégica para os edifícios particulares notificados para PEUC, apresenta-se como foco de importância as seguintes modalidades: (1) 
Acolhimento Institucional Intensivo; e (2) Aluguel de Imóveis Privados para Abrigamento Transitório. O documento também apresenta as seguintes condições de readequação:

Alguns desses edifícios não se viabilizam para uso habitacional de interesse social devido aos altos custos de reforma para constituição de unidades habitacionais completas (com banheiro, cozinha e/ou área de serviço individualizados), mas podem ser adaptados para o serviço de moradia social com reformas menores (eventualmente subsidiadas) que podem produzir unidades incompletas (com banheiro, cozinha e/ou área de serviço compartilhados). (PREFEITURA MUNICIPAL DE SÃO PAULO, 2016, p. 42).

No entanto, o texto ficou parado na Comissão de Política Urbana, o que indica o não interesse em realizar um enfrentamento ao capital imobiliário ${ }^{9}$. Neste cenário, observa-se que há um afastamento entre a ordem jurídica e a prática da gestão dos espaços urbanos. É importante salientar que esta ação é legitimada pelo consenso em torno da estratégia de criminalização da pobreza (SVAMPA, 2007). As classes trabalhadoras empobrecidas carregam o estigma desta condição, que está presente nas experiências de ocupações urbanas.

Segundo os dados da Secretaria de Habitação do Município, em 2018, em toda cidade de São Paulo totalizavam-se 206 ocupações de prédios, com cerca de 45 mil pessoas de diferentes trajetórias de vida. No centro, havia cerca de 75 ocupações, totalizando 3.503 famílias. Nestes locais, os domicílios são improvisados precariamente por seus moradores e normalmente liderados por algum movimento social.

Nas cercanias do quadrilátero analisado, há diversos prédios ocupados. O site Centro Ocupado $^{10}$ listou, dentre as ocupações, algumas de maior expressão, organizadas por movimentos sociais de moradia. São elas: Avenida 9 de Julho, 216; Avenida Cásper Líbero, 339; Avenida Ipiranga, 879; Avenida Prestes Maia, 911; Avenida Rio Branco, 47; Avenida Rio Branco, 53; Avenida São João, 288; Avenida São João, 354; Avenida São João, 588; Rua 24 de Maio, 207; Rua 7 de Abril, 176; Rua Capitão Salomão, 55; Rua Conselheiro Crispiniano, 79; Rua Conselheiro Crispiniano,311; Rua Conselheiro Nébias, 314; Rua Florêncio de Abreu, 48; Rua General Couto de Magalhães, 381; Rua José Bonifácio, 137; Rua José Bonifácio, 237; Rua Líbero Badaró, 190; Rua Marconi, 138; Rua Martins Fontes, 180; Rua Mauá, 340; Rua Quintino Bocaiúva, 242; Rua São Francisco, 77; e Rua Xavier de Toledo, 150.

As ocupações revelam que a urbanização exerceu uma função determinante na absorção de capitais excedentes, em escala geográfica consecutivamente ampliada. Mas, ao custo do impulsivo

\footnotetext{
${ }^{9}$ Em meados de agosto de 2019, foi realizada uma Audiência Pública para retomar a discussão do Projeto de Lei com a participação dos movimentos sociais de moradia.

${ }^{10}$ Disponível em: https://centroocupado.wordpress.com/sobre/. Acesso em: 29 set. 2019.
} 
processo de destruição criativa, foram desapropriadas as populações que compuseram a força de trabalho do regime de acumulação capitalista, sendo a elas negado qualquer direito à cidade. Assim, uma das respostas a essa dinâmica é a ocupação de imóveis por movimentos sociais que lutam pelo cumprimento do artigo 182 da Constituição Federal, que versa sobre o uso social da propriedade.

Maricato e Fecchio (1992) destacam que a organização popular na cidade de São Paulo deriva das condições apresentadas durante o período de forte urbanização, especificamente, 1970 e 1980. Havia ainda, segundo a autora, uma pauta extensa de reivindicações que, muitas vezes, se conectava com os assuntos derivados da fábrica, lembrando que, de 1970 a 1990, o movimento operário era presente nas organizações. Importantes entidades de luta pela terra urbana foram, então, fundadas nesse período. Segundo a autora, havia a:

ANSUR, Articulação Nacional do Solo Urbano e a União dos Movimentos de Moradia, que vieram juntar-se ao MUF - Movimento Unificado de Favelas (âmbito São Paulo e regiões próximas) e FAFERH (Federação de Associações de Favelas do Rio de Janeiro). (MARICATO; FECCHIO, 1992, p. 26).

A articulação pró-moradia se tornou nacional com a criação, em 1990, do Movimento Nacional pela Luta da Moradia, em Goiânia. Em São Paulo, apenas no governo de Luíza Erundina (1989-1993) houve espaço para uma discussão mais ampla da moradia na cidade: "só a partir de tamanho avanço da organização popular, as associações conseguiram participar das decisões arquitetônicas dos projetos, estabelecer o processo de trabalho e a ser empregado e acompanhar os aspectos financeiros da obra" (MARICATO; FECCHIO, 1992, p. 29).

No entanto, somente a partir do final da década de 1990 o centro começou a ser requisitado pelos movimentos de moradia. O centro garantia-Ihes certa visibilidade, o que não acontecia nas periferias. Uma líder do movimento do centro conta:

O movimento de moradia do centro surgiu em divergência com outros movimentos sociais, a gente sempre lutou para que as pessoas viessem morar nas áreas urbanizadas da cidade onde tivesse acopladas a elas saúde, transporte, educação, cultura lazer, e que as famílias não fossem jogadas em grandes glebas, porque quando a família é jogada em uma zona onde não tem acesso, elas automaticamente ficam isoladas. Então, em 1993 nós decidimos que iríamos ocupar a região central de São Paulo, porque havia um grande vazio urbano, hoje agente em $\mathbf{4 9 2}$ mil imóveis vazios, sem função social, eu não falo da propriedade, porque título a gente só dá a quem cuida, o vazio urbano na cidade de São Paulo é maior do que o número de famílias que não tem onde morar. Há um grande estigma também quando a gente fala de movimento sem teto, porque muitos confundem com moradores em situação de rua. Esse tem um outro trânsito. $O$ trabalhador sem teto é aquele que não tem um moradia, porque o movimento não incentiva a propriedade, nós não queremos proprietários, não queremos um novo núcleo de especuladores, o que nós 
queremos formar são cidadão conscientes sabedores de seus direitos e deveres, o movimento do sem teto faz esse fluxo de inclusão, a gente descentraliza o poder, estamos na audiência públicas, dos conselhos, municipal, Estadual, nós estamos dentro das câmaras, a gente discute a cidade, (...) o objetivo é ter um cidade inclusiva. (Entrevistada 1, Ocupação 9 de julho. Entrevista realizada em 26/08/2018, grifos nossos).

Deste modo, ainda acompanhando o relato da líder, feito em 2018, verifica-se que o fenômeno das ocupações dos edifícios vazios exibia os conflitos sociais e econômicos presentes na cidade de São Paulo. Os movimentos aglutinavam famílias que se utilizavam das ocupações para sobreviverem frente a perda do poder de compra dos salários no anos 90.

Os moradores das ocupações são trabalhadores do centro da cidade que possuem trajetórias de deslocamento variadas na cidade. Há, entre eles, a esperança de que o poder público, sensibilizado ou pressionado por pedidos de reintegração de posse, implemente políticas públicas que visem o atendimento de sua demanda por moradia. Em São Paulo, em 2018, havia 149 entidades cadastradas no Programa do Governo Federal Minha Casa Minha Vida (PMCMV), segundo a Secretaria de Habitação.

As ocupações, segundo as lideranças, têm os seguintes objetivos: implementação de políticas habitacionais de interesse social na área central, melhoria na localização das habitações de interesse social, ampliação do atendimento a famílias de renda familiar entre um e três salários mínimos e maior participação dos movimentos sociais no direcionamento das políticas habitacionais. (GFAU, 2002).

Em 2018, eram 3.300 mil famílias vivendo em ocupações no centro de São Paulo. Entre as ocupações, encontra-se próximo à Estação da Luz o maior edifício ocupado da América Latina, o Prestes Maia, uma antiga fábrica têxtil de 21 andares e com dois blocos residenciais, abrigando 478 famílias, aproximadamente duas mil pessoas, desde 2010. A ocupação é coordenada pelo Movimento Moradia na Luta por Justiça (MML) e já resistiu a 26 ordens de despejo. Porém, em 2015, o Governo Municipal comprou o local para construir 283 apartamentos e regularizar a situação dos moradores. Enquanto as reformas não são realizadas, o edifício continua em situação precária, com paredes tomadas pela umidade, janelas sem vidros tampadas com pedaços de madeira e chuveiros compartilhados, ao mesmo tempo em que os habitantes improvisam no local serviços para suprir suas demandas, como espaços de comércio e de cuidado com as crianças.

Em maio de 2018, resultado de condições precárias, o edifício de 24 andares Wilton Paes de Almeida, propriedade do Governo Federal e antiga sede da Polícia Federal, pegou fogo e desabou no centro de São Paulo. O prédio era ocupado por 372 moradores, cerca de 146 famílias. Abandonado desde 2003, o edifício passou por diversas ocupações entre 2015 e 2018. Quando o prédio desabou, a 
ocupação era coordenada pelo Movimento Social de Luta por Moradia (MSLM). Após o trágico desabamento, que fez onze vítimas fatais, a discussão sobre ocupações pelos movimentos de moradia ganhou destaque negativo na mídia nacional, que pouco debateu as reais causas da tragédia e, em alguma medida, passou a criminalizar seus moradores.

No entanto, as ações e práticas empenhadas pelos movimentos sociais despertam o entendimento de que a resistência, em um primeiro momento, não é uma opção, e sim uma questão de sobrevivência cotidiana que garanta os benefícios sociais mínimos, tais como comer, morar e viver. Entretanto, estas estratégias de ação têm apresentado formas de resistência que politizam a dimensão cotidiana e colocam em xeque o espaço público oficial (OLIVEIRA; AMARAL E SILVA, 2018).

Zibechi (2008), ao analisar os vinte anos de lutas sociais em territórios latino-americanos, aponta que estas experiências têm promovido uma nova organização social, e os territórios servem ao mesmo tempo como espaços de sobrevivência e como lugar de construção de uma dimensão sociopolítica. Uma das características evidenciadas pelo autor é a capacidade de auto-organização apresentada em algumas ações, tais como: as formas de tomada de decisões, a organização em redes de solidariedade entre os diversos grupos, as práticas de ensino e educação, as festas, os modos de produção, as estratégias de ocupação, enfim, o controle popular dos territórios. Neste sentido, uma importante líder do movimento de moradia de São Paulo, em entrevista em 2018, esclarece: "ocupar é um resgate da área abandonada, é uma questão sanitária". Trata-se, portanto, do controle da cidade, entendida como espaço de vida.

A seguir, apresenta-se um estudo etnográfico de uma ocupação localizada ao lado da Praça da Sé, com o objetivo de evidenciar os aspectos das sociabilidades presentes em quadros de vulnerabilidade e que expressam outras estratégias de ocupação, uso e controle popular dos territórios. $O$ nome da ocupação não será exposto em respeito aos princípios éticos adotados neste artigo.

\section{EXPERIÊNCIA DE OCUPAR E RESISTIR: NOVAS FORMAS DE CONTROLE DO TERRITÓRIO}

Observa-se, ao caminhar pela rua José Bonifácio, no Triângulo da Sé, na cidade de São Paulo, em meio a comércios de todas as qualidades (supermercados, lojas de roupas, restaurantes populares e de grandes redes de fast-food, entre outros), um prédio de doze andares, com portão de latão um pouco envelhecido e um entra-e-sai de pessoas controlado por um porteiro não uniformizado. Em cidades como São Paulo, não haveria nada de anormalidade na cena narrada não fosse a bandeira de 
um movimento social, indicando que ali se luta por moradia ${ }^{11}$. A ocupação em questão acolhe cerca de 150 famílias. O prédio foi ocupado em 2012 e se caracteriza como uma ocupação "moral”, ou seja, é gerida por um movimento social de expressividade na cidade e assume a preocupação com o direito à cidade e, sobretudo, com a utilização de espaços subutilizados para moradia.

Trata-se também de uma ocupação de caráter familiar. Isso significa que a chegada até ela se deriva de uma rede de contatos, envolvendo amigos ou familiares, estabelecida no próprio Triângulo da Sé. Muitos moradores também se conhecem de outras experiências de ocupações ou trabalho, assim, circulam entre eles informações sobre a organização dos espaços, o que, de alguma forma, os faz optarem por estar em uma ou em outra.

Ainda é importante ressaltar que os moradores da ocupação em questão possuem diferentes trajetórias na cidade de São Paulo, sendo que algumas famílias vêm de outras ocupações urbanas, de outros estados brasileiros e de outros países. No período em que se realizou a etnografia, era marcante a presença de famílias latino-americanas e africanas que moravam na região do Triângulo da Sé.

O prédio da rua José Bonifácio tinha função comercial antes de ser abandonado e ocupado, desse modo, necessitaria de várias adaptações para se transformar em moradias particulares. Porém, já se provou que, em alguns casos e a partir de projetos de arquitetura, a adaptação é possível.

Estar no Triângulo da Sé é estratégico para os moradores da ocupação em questão. Conforme relatado por participantes da pesquisa ${ }^{12}$, estar na Sé é estar próximo dos equipamentos urbanos que utilizam com frequência, do trabalho e de uma imensa rede de apoio de instituições religiosas e não governamentais, que garantem, por exemplo, que não passassem fome na falta de recursos, pois "sempre há na Sé alguém distribuindo marmita", como relatou uma moradora em uma visita. Ademais, trata-se de o lugar onde se consegue algum "corre" com facilidade, seja atuando na limpeza do entorno, seja como propagandista de operadoras de celular e diferentes comércios locais.

Em 2019, o prédio possuía doze andares, todos ocupados e divididos entre cerca de seis famílias, compostas por dois ou três membros cada. As unidades eram separadas por madeirite e fechadas com correntes e cadeados. Por se tratar de unidades dimensionadas entre quatro e cinco

\footnotetext{
${ }^{11}$ O trabalho de campo faz parte de uma pesquisa, realizada entre os anos de 2018 e 2019, que acompanhou famílias acolhidas e ex-moradoras da Ocupação Wilton Paes de Almeida após um incêndio. Neste caso, exclui-se o número do prédio a fim de preservar seus moradores.

${ }^{12}$ A entrada no prédio pela pesquisadora foi mediada por uma família de mulheres e ocorreu em diversos momentos durante a semana e aos domingos. Foram essas mulheres que compartilharam suas histórias em meio a explicações sobre como a ocupação era gerida.
} 
metros quadrados e com pouca circulação de ar, os moradores eram obrigados a sempre deixar as portas entreabertas. Nelas, organizavam-se as camas ou colchões e todos os outros objetos particulares dos moradores, entre eles roupas e eletrodomésticos, como fogões, geladeiras e televisores. Apenas o gás era instalado no lado de fora da unidade.

Alguns moradores recebem doações, são catadores de materiais recicláveis ou se apropriam de objetos que possam ainda ter valor de mercado. Estes materiais são também acumulados dentro das unidades. No entanto, também é comum que vendam os objetos de uso particular, como geladeiras, fogões e camas, em caso de necessidade extrema. Dessa forma, em diferentes momentos do mês, pode-se encontrar as unidades abarrotadas de objetos ou vazias.

Os banheiros eram coletivos e se localizavam juntos a uma lavanderia improvisada, com algumas máquinas de lavar também compartilhadas quando havia relações amistosas entre os vizinhos. Os varais eram colocados junto à janela, conforme demonstra a Figura 6 . As instalações de luz e água eram derivadas de arranjos ilegais, os chamados "gatos", e a rede de internet acessada era dos comércios vizinhos ou disponíveis por meio de bandas $4 \mathrm{G}$.

Os elevadores não funcionavam, e os moradores ou visitantes utilizavam a escada para se deslocar de um andar ao outro. Elas eram pontos de apoio para troca de diversas informações, que iam de vagas de emprego aos preços nos mercados na região. Assim, a escada possibilita aos moradores um tipo de encontro face a face em que solidariedade é ativada.

Observou-se que a limpeza do andar respeitava uma escala entre os moradores e era controlada pelo administrador do andar. A portaria era gerida de maneira coletiva, e destacavam-se os seguintes avisos: não é permitida a entrada de estranhos e visitantes sem o devido registro de RG e horários de entrada e saída. Diversos conflitos foram relatados por conta da entrada e saída de visitantes, muitos dos quais tentavam se tornar moradores permanentes sem passar pela avaliação criteriosa do movimento. Para estar na ocupação da José Bonifácio, era necessário estar comprometido com a luta, mas nem todos os moradores diziam ter tempo disponível para acompanhar o movimento. 
Fotografia 1: muros

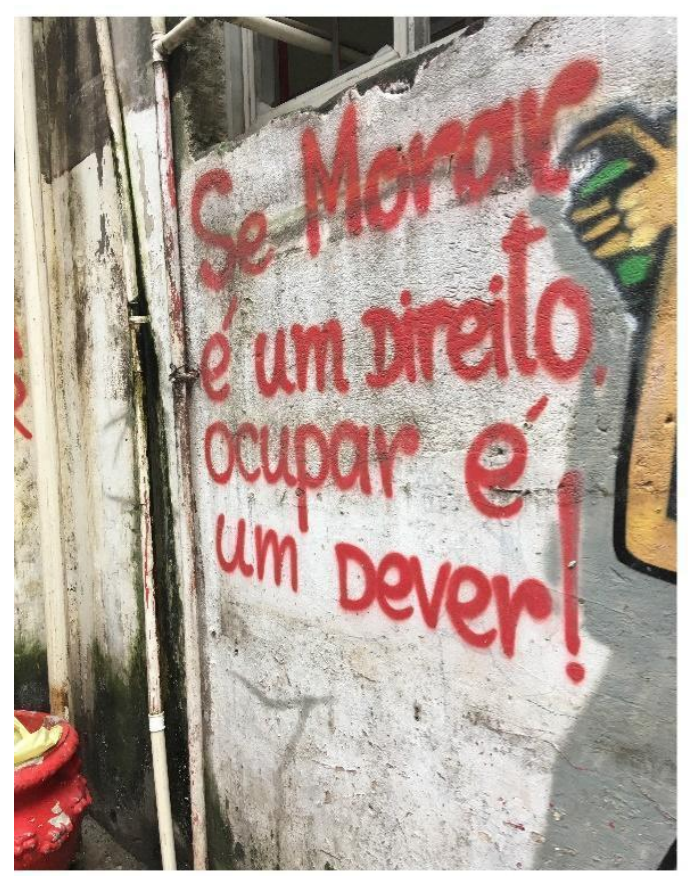

Fotografia 2: Por dentro da ocupação

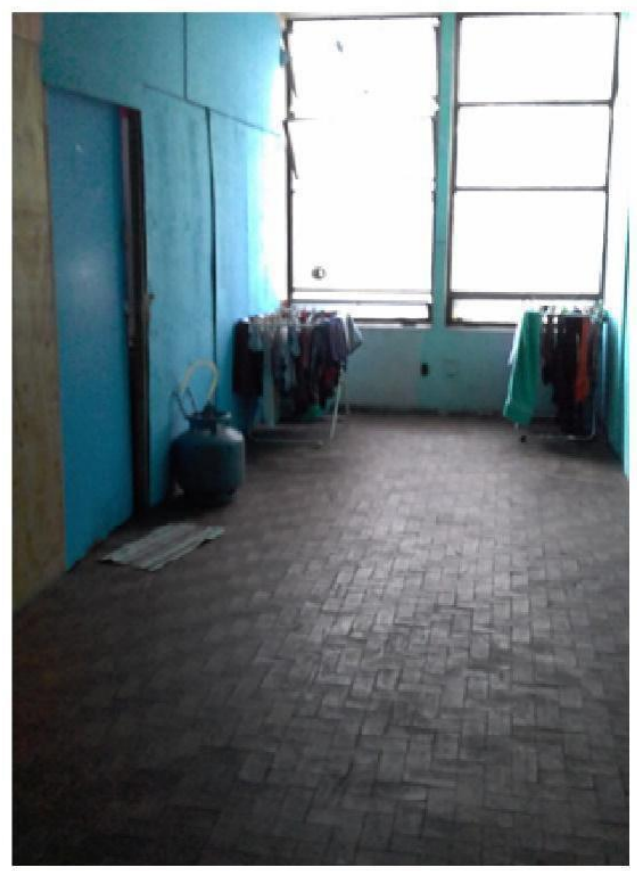

Fonte: arquivos da pesquisa.

Fotografia 3: Muro grafitado "Quem não luta tá morto - MSTC

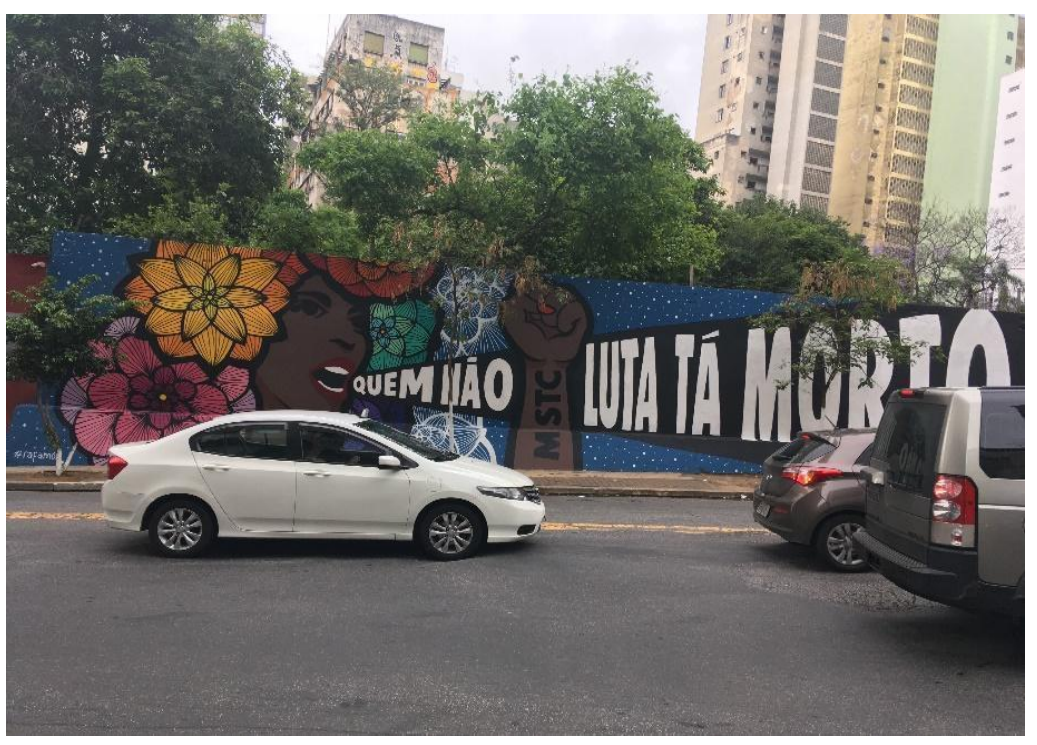

Fonte: arquivos da pesquisa.

As normas internas de convivência eram bastante rígidas e estar ou não na ocupação dependia do quão disponível estava o morador para aceitar as regras, sobretudo a principal delas, vinculada à 
participação política, além de realizar uma contribuição mensal, o chamado "aluguel", que serviria para a manutenção do prédio.

O movimento exigia do morador a participação nas reuniões semanais, nas manifestações vinculadas à causa ou relacionadas ao acesso a direitos sociais. Acompanhar os Conselhos Municipais e Estadual de Moradia, ocupar audiências públicas e, quando disponível, participar da "festa", ato de ocupação de outros prédios, considerando que a luta deve ser maior que o interesse particular e a demanda de famílias em busca de um lugar para morar em São Paulo, era uma constante.

O movimento, quando era responsável por mais de uma ocupação, estimulava a criação de vínculos entre seus moradores por meio de almoços e encontros coletivos, para que eles entendessem que estavam na mesma condição e a luta deveria ser permanente. No entanto, a formação política dos moradores das ocupações não é simples, os conflitos são permanentes, principalmente quanto à participação nas reuniões após o horário de trabalho. A retirada de moradores, que desrespeitam as regras, também é quase sempre traumática e envolve muitas ameaças e conflitos.

A proposta do movimento que controla a ocupação supracitada refere-se à luta pelo direito à moradia digna (TATAGIBA; PATERNIANI; TRINDADE, 2012), o que não deriva, necessariamente, da propriedade privada. Por isso, entende-se que as novas propostas trazidas pelos movimentos sociais urbanos podem subverter lógicas da gestão capitalista dos territórios. No entanto, as famílias moradoras das ocupações, normalmente, são cadastradas pela Prefeitura Municipal e aguardam uma moradia de caráter social. Mesmo que a fila seja enorme e o tempo de espera perdure anos, o "sonho" da casa própria (como propriedade) ainda é marcante nos discursos dos moradores das ocupações.

Sabe-se que a ocupação de prédios abandonados no centro é legítima, mas é comum que os moradores as citem como "invasões". Dependendo da situação, os moradores dizem que "pagam aluguel", na tentativa de controlar os estigmas sociais que configuram o contexto das ocupações. Verificam-se nas trajetórias, também, a circulação entre ocupações, aluguéis em pensões e hotéis do centro, e mesmo períodos em que se vive em abrigos municipais ou na rua.

Dessa forma, a luta por moradia se resume ao movimento como questão de vida ou morte: "quem não luta tá morto", ou seja, para fazer cumprir um direito garantido constitucionalmente, hoje, na cidade de São Paulo, uma massa imensa de moradores urbanos precisa se engajar em movimentos sociais para pressionar o Estado a criar políticas públicas que lhes garantam direitos fundamentais assegurados constitucionalmente. Os movimentos sociais, por meio das ocupações, atuam de maneira a questionar os gestores públicos da cidade e os proprietários sobre a subutilização de imóveis que não cumprem a função social da propriedade. Neste artigo, a análise do fenômeno da vacância 
imobiliária representa uma das estratégias da gestão neoliberal do espaço urbano, e a investigação sobre as ocupações urbanas na região central da cidade de São Paulo elucida novas formas de produzir e organizar o território.

\section{CONSIDERAÇÕES FINAIS}

Diante do cenário atual, torna-se imprescindível repensar a aplicabilidade de instrumentos urbanísticos descritos no Estatuto da Cidade e que deveriam orientar a formulação dos planos diretores. Neste sentido, salienta-se a demarcação das Zonas Especiais de Interesse Social (ZEIS), relacionadas aos imóveis vazios e subutilizados localizados em áreas providas de infraestrutura e que, portanto, amenizariam a segregação e a precariedade sofrida por determinados grupos sociais, garantindo, assim, o acesso da população de baixa renda à terra urbanizada.

Existem algumas experiências significativas relacionadas à habitação social na área central de São Paulo. Elas envolvem movimentos sociais e técnicos, como, por exemplo, as desapropriações que ocorreram durante o governo do prefeito Haddad (2013-2016). Para que pudessem continuar e se transformar em locações sociais e reformas de edifícios antigos, como o Riachuelo, onde os elevadores foram trocados, grandes esforços e recursos foram demandados. Porém a escala de produção é muito pequena diante do déficit habitacional, como explica o coordenador do Movimento de Moradia do Centro.

A habitação social necessita ser prioridade nas políticas públicas. Imóveis subutilizados devem ser destinados à sua produção, especialmente em cidades como São Paulo, onde o déficit habitacional é grande e o número de vacâncias também. Aliada a essa iniciativa, é indispensável a concessão de subsídios para o financiamento e desenvolvimento de programas de aluguel social, por exemplo, pois só assim essas habitações serão acessíveis à população de baixa renda.

Feito o levantamento de dados em campo sobre o uso e ocupação, o gabarito e a forma como os edifícios tombados são utilizados, além da análise teórica de conteúdos produzidos por pesquisadores do desenvolvimento urbano, o principal objetivo deste trabalho foi identificar como o capitalismo interfere na dinâmica socioespacial da cidade contemporânea. A partir desses fatores analisados, aborda-se o desenvolvimento local e suas consequências, como a apropriação do espaço público, a exclusão social, a baixa densidade habitacional, a vacância imobiliária e a ocupação de edifícios por movimentos sociais. 
Tal organização evidencia que o desenvolvimento urbanístico acontece em função de interesses que envolvem o capital imobiliário, como, por exemplo, a localização das novas unidades habitacionais construídas cada vez mais afastadas do centro histórico, onde acabam se concentrando em imóveis mais antigos. A durabilidade é um dos atributos mais valorizados pelo mercado de habitação, porém se torna menos vantajoso investir na manutenção de uma unidade com o mesmo padrão de qualidade de sua construção original do que investir na construção de uma nova casa com o mesmo padrão em outro local. Isso leva ao abandono da residência original.

Unidades de habitação cada vez mais precárias e falta de investimentos públicos em áreas centrais explicam a predominância de famílias de menor renda em imóveis abandonados, enquanto moradores com maior poder aquisitivo optam por substituir as opções de mobilidade, proporcionadas pela localização central das unidades, pelo consumo de terrenos maiores. Logo, os proprietários de edificações centrais escolhem não vender seus imóveis, acreditando que uma futura requalificação urbana suba os preços.

Toda essa dinâmica leva à vacância imobiliária e à apropriação do espaço público por agentes privados, como se pode notar em muitos lotes destinados à ocupação mista, usados apenas comercialmente, sendo muito deles grandes empresas e grandes marcas. Consequentemente, a iniciativa privada passa a ditar as regras e a dinâmica do espaço urbano, como, por exemplo, as atividades destinadas aos edifícios considerados patrimônios culturais.

Portanto, a requalificação e a dinâmica do meio urbano devem ser questões de políticas públicas, e não do mercado privado, de modo que se chegue cada vez mais perto da supressão do o déficit habitacional e do adequado aproveitamento da rede de transporte público que os centros urbanos oferecem.

Neste cenário, as ocupações configuram-se como uma resposta aos processos de exclusão e expropriação de uma parcela significativa da sociedade. Ao se compreender que as dimensões da luta perpassam a relação entre resistência, sobrevivência e enfrentamento, a experiência das ocupações aponta para uma politização da dimensão cotidiana. Estas estratégias de controle popular dos territórios têm sido capazes de pautar as problemáticas e dinâmicas urbanas de exclusão e apresentar uma leitura técnico-política que potencializa e legitima suas ações e proposições para uma produção social do espaço comprometida com a justiça social e urbana. 


\section{REFERÊNCIAS BIBLIOGRÁFICAS}

ARCOVERDE, Léo; CERQUEIRA, Rosana. São Paulo tem mais de 130 imóveis ocupados, aponta levantamento da Prefeitura. Globo News, São Paulo, 16 out. 2018. Disponível em: https://g1.globo.com/sao-paulo/noticia/sao-paulo-tem-mais-de-130-imoveis-ocupados-apontalevantamento-da-prefeitura.ghtml. Acesso em: 5 dez. 2018.

BARBOSA, Eunice. Evolução do uso residencial na área central do Município de São Paulo. São Paulo: Universidade de São Paulo, Escola Politécnica, 2001.

BRASIL. Constituição da República Federativa do Brasil de 1988. Brasília, 1988. Disponível em: https://www.senado.leg.br/atividade/const/con1988/con1988_03.07.2019/art_182_.asp. Acesso em: 28 set. 2019.

BONFIM, Valéria. O Centro Histórico de São Paulo: a vacância imobiliária, as ocupações e os processos de reabilitação urbana. Cadernos Metrópoles, São Paulo, n. 12, p. 27-48, 2004. Disponível em: https://revistas.pucsp.br/index.php/metropole/article/view/8808. Acesso em: 5 dez. 2018.

CANETTIERI, Thiago. O debate sobre as ocupações urbanas revisitado: entre o vício (da virtude) e a virtude (do vício), a contradição. Revista E-Metropolis, v. 29, p. 32-39, 2017.

CARTY, Carolina Gabriel; COSTA, Luiz Augusto Maia. Vacância como materialização do processo de dispersão urbana. O centro histórico de Campinas, 2005-2014, um estudo de caso. Arquitextos, São Paulo, ano 17, n. 204.05, mai. 2017. Disponível em:

https://vitruvius.com.br/revistas/read/arquitextos/17.204/6561. Acesso em: 21 fev. 2020.

CIDADE DE SÃO PAULO. Turismo. Triângulo SP. Infocidade, São Paulo, 04 set. 2019. Disponível em: https://www.prefeitura.sp.gov.br/cidade/secretarias/turismo/eventos/index.php?p=274556. Acesso em: 29 set. 2019.

CIDADE DE SÃO PAULO. Urbanismo e licenciamento. Apresentação. Infocidade, São Paulo, 19 mar. 2020. Disponível em:

https://www.prefeitura.sp.gov.br/cidade/secretarias/urbanismo/dados_estatisticos/info_cidade/ind ex.php/. Acesso em: 5 dez. 2018.

COTELO, Fernando. Padrões espaciais de ociosidade imobiliária e o Programa Morar no Centro da Prefeitura de São Paulo (2001-2004). Cadernos Metrópoles, São Paulo, v. 11, n. 22, p. 615-635, 2007. Disponível em: https://revistas.pucsp.br/metropole/article/view/5950/4303. Acesso em: 5 dez. 2018.

DALLARI, Dalmo. Direitos humanos e cidadania. 2 ed. São Paulo: Moderna, 2004. 112 p.

FERREIRA, Maria Nazareth. Os desafios da produção científica no neoliberalismo: as culturas e a comunicação subalternas. Comunicação e Política, Rio de Janeiro, v. 25, n. 01, 2007.

GRÊMIO DA FACULDADE DE ARQUITETURA E URBANISMO DA USP (GFAU). Entrevistas com lideranças de movimentos sociais. Revista Caramelo, São Paulo, n. 10, 2002.

HARVEY, David. A produção capitalista do espaço. 2 ed. São Paulo: Annablume, 2005. 252 p. 
HARVEY, David. Cidades rebeldes: do direito à cidade à revolução urbana. 1 ed. São Paulo: Martins Fontes, 2014. $296 \mathrm{p}$.

HARVEY, David. O novo imperialismo: acumulação por desapossamento (Parte II). Revista Lutas Sociais, São Paulo, n. 15/16, p. 21-34, 2006.

HOUAISS, Antônio. Dicionário Houaiss da Língua Portuguesa. São Paulo: Objetiva, 2001.

KARA-JOSÉ, B. Políticas culturais e negócios urbanos: a instrumentalização da cultura na revalorização do centro de São Paulo (1975-2000). São Paulo: Annablume/Fapesp, 2007.

LEFEBVRE, Henri. O direito à cidade. São Paulo: Centauro, 1968.

LELIS, Natália. Ocupações urbanas: a poética territorial da política. Revista Brasileira de Estudos Urbanos e Regionais, Recife, v.18, n. 3, p. 428-444, set./dez. 2016.

MARICATO, Ermínia; FECCHIO, F. A luta pelo direito de morar. Revista Travessia, São Paulo, Ed. CEM anos 05, n. 14, p. 25-30, 1992.

MARICATO, Ermínia. As ideias fora do lugar e o lugar fora das ideias. In: ARANTES, Otília; VAINER, Carlos; MARICATO, Ermínia. Cidade do pensamento único: desmanchando consensos. Petrópolis: Vozes, 2002. p. 121-192.

MARICATO, Ermínia. Reabilitação de centros urbanos e habitação social: gestão da terra urbana e habitação de interesse social. Campinas: Pontifícia Universidade Católica de Campinas, 2000.

MATTOS, Talita. Gentrificação e humanização: um desafio para a cidade de São Paulo. São Paulo: CELACC, 2017.

MEYER, Regina Maria Prosperi; DORA GROSTEIN, Marta; BIDERMAN, Ciro. São Paulo Metrópole. São Paulo: Edusp/Imprensa Oficial do Estado de São Paulo, 2004.

MINGIONE, Enzo. Urban poverty in the advanced industrial world: concepts, analysis and debates. New York: Blackwell, 1999.

MOTTA, Diana Meirelles da; PÊGO, Bolívar. Licenciamento Ambiental para o Desenvolvimento Urbano: avaliação de instrumentos e procedimentos. Rio de Janeiro: IPEA, 2013.

NADALIN, Vanessa Gapriotti; BALBIM, Renato. Padrões espaciais da vacância residencial brasileira. In: ANAIS do circuito de debate acadêmico. Brasília: IPEA, 2011.OLIVEIRA, Denis.; AMARAL E SILVA, Fabiana Félix. Metodologias participativas na análise de experiências de movimentos sociais nas periferias Latino-Americanas. Revista Extraprensa, v. 11, n. esp, p. 6, 28 jun. 2018.

PEREIRA, Pablo. Ocupações no centro de São Paulo vivem sob riscos. O Estado de São Paulo, São Paulo, 3 mai. 2018. Disponível em: https://saopaulo.estadao.com.br/noticias/geral,ocupacoes-nocentro-de-sao-paulo-vivem-sob-riscos,70002292568. Acesso em: 5 dez. 2018.

PESAVENTO, Sandra. Cidade, espaço e tempo: reflexões sobre a memória e patrimônio urbano. Cadernos do LEPAARQ - Textos de Antropologia, Arqueologia e Patrimônio, Pelotas, v. 2, p. 9-17, 2005. 
PREFEITURA MUNICIPAL DE SÃO PAULO. Geosampa: Sistema de consulta do mapa digital da cidade de São Paulo. São Paulo, s./d. Disponível em:

http://geosampa.prefeitura.sp.gov.br/PaginasPublicas/_SBC.aspx. Acesso em: 5 dez. 2018.

PREFEITURA MUNICIPAL DE SÃO PAULO. Plano Municipal de Habitação de São Paulo: caderno para discussão pública. São Paulo, jun. 2016. Disponível em:

http://www.habitasampa.inf.br/files/CadernoPMH.pdf. Acesso em: 29 set. 2019.

PREFEITURA MUNICIPAL DE SÃO PAULO. Secretaria de Habitação do Município. Prefeitura concluiu visita às ocupações com três interdições e criação de grupo de trabalho permanente | Secretaria Municipal de Habitação | Prefeitura da Cidade de São Paulo. 2018.

PREFEITURA MUNICIPAL DE SÃO PAULO. Projeto de Lei n. 619/16 (Plano de Habitação Municipal. PROJETO DE LEI EXECUTIVO № 619 DE 21 DE DEZEMBRO DE 2016 «Catálogo de Legislação Municipal (prefeitura.sp.gov.br).

PREFEITURA MUNICIPAL DE SÃO PAULO. Secretaria Municipal de Urbanismo e Licenciamento | Secretaria Municipal de Urbanismo e Licenciamento | Prefeitura da Cidade de São Paulo. 2017.

PREFEITURA MUNICIPAL DE SÃO PAULO. INFOCIDADE. Dados demográficos dos distritos pertencentes às Subprefeituras. Dados demográficos dos distritos pertencentes às Subprefeituras Secretaria Municipal de Subprefeituras | Prefeitura da Cidade de São Paulo. 2018.

REIS FILHO, Nestor Goulart et al. Dez anos de diálogos sobre dispersão urbana. São Paulo: FAUUSP, 2017. $683 \mathrm{p}$.

RIBEIRO, Eduardo. Lideranças das primeiras ocupações no Centro de SP falam sobre a trajetória do movimento. Vice Brasil, São Paulo, 7 mai. 2018. Disponível em:

https://www.vice.com/pt_br/article/zmgjmy/ocupacoes-centro-sp-liderancas. Acesso em: 5 dez. 2018.

SANDRONI, Paulo. A dinâmica imobiliária da cidade de São Paulo: esvaziamento, desvalorização e recuperação da região central. In: PREFEITURA DE SÃO PAULO. Caminhos para o Centro: estratégias de desenvolvimento para a região central de São Paulo. São Paulo: PMSP/EMURB/CEBRAP/CEM, 2004.

SANTOS, Milton. Sociedade e espaço: a formação social como teoria e como método. Boletim Paulista de Geografia, São Paulo, n. 54, p. 81-100, 1977.

SAULE JÚNIOR, Nelson. O direito à cidade como centro da nova agenda urbana 3. Ipea Boletim Regional, Brasília, p. 76, jul./dez. 2006.

SVAMPA, Maristella. Movimientos sociales y escenario político: las nuevas inflexiones del paradigma neoliberal en America Latina. Observatorio Social de América Latina, CLACSO, Buenos Aires, 2007.

TATAGIBA, Luciana; PATERNIANI, Stella Zagato; TRINDADE, Thiago A. Ocupar, reivindicar, participar: sobre o repertório de ação do movimento de moradia de São Paulo. Opinião Pública, Campinas, v. 18, p. 399-426, 2012. 
TRINDADE, Thiago A. Protesto de democracia: ocupações urbanas e Luta pelo direito à cidade. Jundiaí: Paco, 2018.

VILLAÇA, Flávio. Espaço intra-urbano no Brasil. São Paulo: Studio Nobel/FAPESP/Lincoln Institute, 1998.

VILLAÇA, Flávio. São Paulo: segregação urbana e desigualdade. Estudos Avançados, São Paulo, v. 25, n. 71, p. 37-58, abr. 2011.

ZIBECHI, Raúl. Territórios em resistência: cartografia política das periferias urbanas latinoamericanas. Buenos Aires: Lavaca, 2008.

Trabalho recebido em 13 de outubro de 2019

Aceito em 10 de março de 2021 